\title{
Fever of Unknown Origin: A Patient with Intermittent Idiopathic Fever for Three Years
}

\author{
Nedeni Bilinmeyen Ateş: Üç Yıldır Ateşi Olan Bir Hasta
}

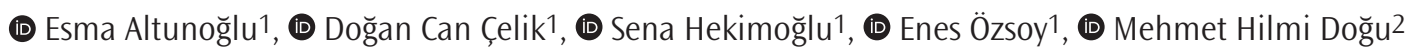

1 University of Health Sciences Turkey, İstanbul Training and Research Hospital, Clinic of Internal Medicine, ìstanbul, Turkey

2University of Health Sciences Turkey, Istanbul Training and Research Hospital, Clinic of Hematology, İstanbul, Turkey

\begin{abstract}
Fever of unknown origin (FUO) is defined as a fever $\geq 38.3$ ${ }^{\circ} \mathrm{C}$ on at least three occasions over a period of at least three weeks, with no obvious diagnosis despite one week of inpatient investigations. Over 200 infections, neoplasm and inflammatory diseases can lead to an FUO. The definition of FUO is difficult, even though more sophisticated diagnostic tools such as positron emitted tomography and many biochemical and serological assays have become routinely available. However, it is surprising that despite the improvement in diagnostic modalities, some FUO still remain undiagnosed. When the diagnosis of FUO was not defined, invasive tests such as biopsies may be useful. Bone marrow biopsy is an accepted method in FUO to uncover haematological malignancies and certain infections. We report a case of prolonged fever 4-5 times each year for 3 years which has presented FUO. She had bone morrow biopsy and was diagnosed with T-cell large granular lymphocytic leukaemia.
\end{abstract}

Keywords: Fever of unknown origin, bone morrow biopsy, leukemia

\section{ÖZ}

Nedeni bilinmeyen ateș; ayaktan hastalarda en az üç hafta hastanede bir hafta süre ile tetkik edilmesine rağmen en az üç ölçümde ateșin $\geq 38,3^{\circ} \mathrm{C}^{\prime}$ nin üzerinde olduğu durum olarak tanımlanır. Enfeksiyonlar, maliniteler, enflamatuvar hastalıklar olmak uzere 200 üzerinde hastalık nedeni bilinmeyen ateșin nedeni olabilir. Pozitron yayınlayıcı tomografi ve birçok biyokimyasal, serolojik ilerlemiş tanı metotlarının rutin olarak kullanılmasına rağmen nedeni bilinmeyen ateșin tanısını koymak zordur. Nedeni bilinmeyen ateşin ilerlemiş tanı metotlarına rağmen tanısı konulamadığında biyopsi gibi invazif girişimler yapılır. Kemik iliği biyopsisi ile hemotolojik maliniteler ve bazı enfeksiyonların tanısı konulabilir. Son 3 yılda, senede 4-5 kez ateși olan bir nedeni bilinmeyen ateș olgusunu sunuyoruz. Hastada hematolojik bir malinite; T-hücre büyük granüllü lenfatik lösemi tanısı kemik iliği biyopsisi ile konuldu.

Anahtar Kelimeler: Nedeni bilinmeyen ateș, kemik iliği biyopsisi, lösemi

\section{Introduction}

Fever of unknown origin (FUO) was first described by Petersdorf and Beeson (1) in 1961.

It was defined as a fever greater than $38.3^{\circ} \mathrm{C}$ on several occasions, for a minimum duration of three weeks, without a diagnosis after intensive evaluation and diagnostic tests, and/or with an uncertain diagnosis after conducting investigations for one week in the hospital (2). This definition has been used to compare and contrast FUO in different eras, geographic locations and special patient populations (3). In addition, FUO was differentiated into four classes by Durak and Street (4) in 1991: classical FUO, nosocomial FUO, neutropenic FUO and human immunodeficiency virus (HIV)-associated FUO. Furthermore, they proposed the following definition of an FUO: a minimum diagnostic evaluation of three outpatient visits or three days of in-hospital investigations. Nevertheless, FUO has been used by clinicians to describe febrile illnesses of variable durations.

There are approximately 200 described causes of FUO, which are broadly categorised into infections, rheumatic-inflammatory diseases (such as connective tissue diseases) and malignancies $(2,5)$. Despite extensive work-up and diagnostic advances, up to $51 \%$ of cases remain undiagnosed $(2,5,6)$. The diagnosis of patients with FUO was made by the history and examination findings and laboratory testing, including complete blood count, blood chemistries, blood and urine cultures, C-reactive protein, erythrocyte sedimentation rate, HIV antibody, antinuclear antibody (ANA) and chest X-ray. Sometimes, bone marrow biopsy (BMB) may be needed for the investigation of haematological malignancy or certain infections such as tuberculosis $(7,8)$.
Address for Correspondence/Yazıșma Adresi: Esma Altunoğlu MD, University of Health Sciences Turkey, İstanbul Training and Research Hospital, Clinic of Internal Medicine, İstanbul, Turkey

Phone: +90 5425150871 E-mail: esmaaltunoglu@yahoo.com ORCID ID: orcid.org/0000-0003-0908-1575

Cite this article as/Atıf: Altunoğlu E, Çelik DC, Hekimoğlu S, Özsoy E, Doğu MH. Fever of Unknown Origin: A Patient with Intermittent Idiopathic Fever for Three Years. İstanbul Med J 2020; 21(Suppl 1): 23-25.
Received/Geliș Tarihi: 17.09.2019 Accepted/Kabul Tarihi: 06.08.2020

(C) Copyright 2020 by the University of Health Sciences Turkey, Istanbul Training and Research Hospital/istanbul Medical Journal published by Galenos Publishing House.

(C) Telif Hakkı 2020 Sağlık Bilimleri Üniversitesi Istanbul Ĕgitim ve Araştırma Hastanesi/Istanbul Tıp Dergisi, Galenos Yayınevi tarafından basılmıștır. 
Here, we report the case of a 59-year-old female patient who had fever 3-4 times in each year for three years. We performed a BMB and her diagnosis was T-cell large granular lymphocytic leukaemia.

\section{Case Report}

The patient gave her informed consent.

A 59-year-old Caucasian woman with a recurrent history of chest infections was admitted to our clinic. She complained of worsening of fatigue, cough, chills and high-grade fever, which had been present for 2-3 weeks. Additionally, she had fever 3-4 times each year for three years. The complaints have been gradually increasing since last year. She was admitted to the hospital many times and treated with antibiotherapy and discharged. The patient did not report any other symptoms, including night sweats, weight loss and haemopthisis. She was not on any regular medication and had no history of exposure to ionising radiations or toxic chemicals.

She had been operated for chronic otitis media with effusion in 2010.

Her family history was unremarkable.

Her vital signs were stable. Physical examination at initial presentation revealed an awake, alert, well-nourished and fully oriented patient in no acute distress. There was no palpable lymph node and no joint deformity was observed. Fever: $39.1{ }^{\circ} \mathrm{C}$, blood pressure: $120 / 80 \mathrm{mmHg}$, heart rate: $84 /$ minute rhythmic. On auscultation of lung heard normal breath sounds, and rare rales.

Laboratory results were as follows: complete blood count: Haemoglobin of $9.9 \mathrm{~g} / \mathrm{dL}$, total leukocyte count of $7.22 \times 10^{9} / \mathrm{L}$ and platelet $142,000 /$ $\mathrm{dL}$. Peripheral blood smear: 76.6\% lymphocytes, 19.5\% monocytes, $3.6 \%$ neutrophils, many atypical lymphocytes with azurophilic granules within their cytoplasm and few neutrophils were shown.

The absolute lymphocyte count was 5,553 and absolute neutrophil count was 260 . The coagulation profile was normal. Biochemistry panel and the serologic tests for HIV antibody test and viral hepatitis C and B were unremarkable. Lactate dehydrogenase, liver and kidney function tests were normal. Rheumatoid factor, ANA and other autoimmune markers, antineutrophil cytoplasmic antibody profiles were all negative.

Thorax computed tomography (CT) imaging demonstrated lymphadenomegaly, which were not exceeding $11 \mathrm{~mm}$ in the mediastinum. Abdominal CT showed enlarged spleen and liver.

Positron emitted tomography (PET)/CT scan revealed multiple lymph nodes, which have increased [18F]-fluoro-2-deoxy-D-glucose in the axillary.

Flowcytometry of peripheral blood revealed a population of lymphoid cells that expressed CD2 (\%) 92, CD3 (\%) 90, CD5 (\%) 85, CD8 (\%) 78, CD (\%) 45 72, TCRab (\%) 94. CD4, CD56 and CD 57 were weakly positive.

The patient underwent bone marrow aspiration and biopsy and the flow cytometric study of the bone marrow aspirate. Trephine revealed slightly hypercellular bone marrow, erythroid series was regressive compared to the granulocytic series. Megakaryocytic and granulocytic populations were slightly hyperplasic. There was a noticeable increase in eosinophils. A lymphoid aggregate in the peritrabeculer area and interstitial lymphocytosis were seen. In antigenic investigation, the lymphoid population consisted of mainly CD3 (+) T Iymphocytes and showed intrasinusoidal and interstitial spread. CD4 and CD56 were negative. Otherwise, $\mathrm{CD} 8$, perphorine, granzyme and TIA-1 were positive.

These findings were suggestive adult T-cell large granular lymphocytic leukaemia.

The patient consulted at the department of haematology and an antileukemic therapy was initiated.

\section{Discussion}

Despite the modern diagnostic tools and advanced therapeutic possibilities, FUO remain an unresolved challenge in medicine. FUO may be the symptoms of approximately 200 described causes (2,3). Aetiology may depend on the geography, because in developing countries, the percentage of infections is much higher than in developed countries, where neoplasms and inflammatory diseases are predominant (3). Although there is a common agreement that a detailed patient history and physical examination is crucial in patients presenting with unclear febrile illness. Fever pattern analysis may provide information on the diagnosis (5). The next step for diagnosing FUO is to determine the laboratory tests are that are necessary. Most authors propose multiple blood tests, urinalysis, stool tests, skin tests, cultures of different materials, chest X-ray and ultrasonography of the upper abdomen. If the diagnosis is not determined, another series of tests is proposed: ANA, rheumatoid factor, hepatitis serology, HIV serology, culture for mycobacteria, other bacteria and fungi and echocardiography. When no diagnosis if is found, CT of the neck, chest, abdomen and pelvis; and $\mathrm{PET} / \mathrm{CT}$ if available, should be done. There is increasing evidence in the literature on the utility of CT and/or PET/CT in investigations for FUO (8). These imaging tests are effective in diagnosis infections, lymphoma and furthermore, the diagnosis confirmation or exclusion in $45-75 \%$ of cases. Despite the improvement of diagnostic technologies, especially imaging modalities, still are still undiagnosed FUO. If no diagnosis is achieved, some of investigators proposed a liver and BMB $(8,9)$.

Wang et al. (10) proposed the bone marrow score to guide the need for BMB in FUO for haematological malignancy. The score included leucoerythroblastic changes in peripheral blood smear, thrombocytopenia, anaemia and neutropenia.

Previous studies have shown the presence of cytopenias to be more predictive of BMB findings for haematological malignancies $(11,12)$. Recently, BMB was shown to be useful in several conditions including infection, malignancy and autoimmune diseases, which are all in the differential diagnosis of patients with FUO $(8,13)$.

In the present case, adult T-cell large granular lymphocytic leukaemia was diagnosed with BMB. The diagnosis probably was delayed. She had fever 3 and 4 times each year for 3 years. In the past, she had been administered wide spectrum antibiotics and antipyretics each time it occurred. Therefore, it camouflages the presenting fever and symptom, thereby delaying the diagnosis. 
It is important to search for causes of diseases in patients who had deteriorated conditions. Biopsies must be performed in difficult cases, especially when malignant diseases are suspected.

There is no single standard FUO management protocol. Empiric antibiotics are not indicated unless the patients with FUO are neutropenic. Antibiotics may delay the diagnosis of some occult infections. Empiric glucocorticoids are also not indicated unless there is a strong clinical suspicion for rheumatologic disease (5).

The most critical feature of the diagnosis of patients with FUO is to take a careful history, physical examination and to reassess the patient frequently. A wide variety of diagnostic laboratory tests and imaging studies may be useful in FUO. Cytopenic patients should also undergo BMB.

\section{Ethics}

Informed Consent: The patient gave her informed consent.

Peer-review: Externally and internally peer-reviewed.

Authorship Contributions: Surgical and Medical Practices - E.A., E.Ö., M.H.D.; Concept - E.A., D.C.C..; Design - E.A.; Data Collection or Processing - D.C.C.; Analysis or Interpretation - E.A.; Literature Search - D.C.C.., S.H.; Writing - E.A.

Conflict of Interest: No conflict of interest was declared by the authors.

Financial Disclosure: The authors declared that this study received no financial support.

\section{References}

1. Petersdorf RG, Beeson FB. Fever of unexplained origin: report on 100 cases. Medicine (Baltimore) 1961; 40: 1-30.
2. Brown I, Finnigan NA. Fewer of unknown origin. Stat pearls publishing; 2020. Available from: URL: https://www.ncbi.nlm.nih.gov/books/NBK532265/

3. Davit $\mathrm{H}$ Bor. Approach to the adult with fever of unknown origin. Available from: URL: https://www.uptodate.com/contents/approach-to-the-adult-withfever-of-unknown-origin

4. Durak DT, Street AC. Fever of unknown origin-reexamined and redefined. Curr Clin Top Infect Dis 1991; 11: 35-51.

5. Unger M, Karakinas G, Kerschbaumer A, Winkler S, Aletaha D. Fever of unknown origin revised. Wien Klin Wochenschr 2016; 128: 796-801.

6. Schönau V, Vogel K, Englbrecht M, Wacker J, Schmidt D, Manger B, et al. The value of 18F-FDG-PET/CT in identifying the cause of fever of unknown origin (FUO) and inflammation of unknown origin (IUO): data from a prospective study. Ann Rheum Dis 2018; 77: 70-7.

7. Cunha BA, Lortholary O, Cunha CB. Fever of unknown origin: a clinical approach. Am J Med 2015; 128: 1138.el-1138.el5.

8. Hong FS, Fox LC, Chai KL, Htun K, Clucas D, Morgan S, et al. Role of bone marrow biopsy for fever of unknown origin in the contemporary Australian contex. Intern Med J 2019; 49: 850-4.

9. Tan Y, Lui X, Shi X. Clinical features and outcomes of patients with fever of unknown origin: a retrospective study. BMC Infect Dis 2019; 19: 198.

10. Wang HY, Yang CF, Chiou TJ, Yang SH, Gau JP, Yu YB, et al. A"bone marrow score" for predicting haematological disease in immunocompenent patients with fever of unknown origin. Medicine (Baltimore) 2014; 93: e243.

11. Hot A, Jaisson I, Girard C, French M, Durand DV, Rousset H, et al. Yield bone marrow examination in diagnosis the source of fever of unknown origin. Arch Intern Med 2009; 169: 2018-23.

12. Ben-Baruch S, Canaani J, Braunstein R, Perr YC, Ben-Ezra J, Polliack A, et al. Predictive parameters for a diagnostic bone marrow biopsy specimen in the work-up of fever of unknown origin. Mayo Clin Proc 2012; 87: 136-42.

13. Crispin P, Holmes A. Clinical and pathological feature of bone marrow granulomas: A modern Australian series. Int J Lab Hem 2018; 40: 123-7. 